\title{
The Kurzarbeit model and the sustainable development of Romania Is Romania ready for this model?
}

\author{
Paula MUNTEANU \\ Romanian Academy, Bucharest, Romania \\ pma.munteanu@gmail.com \\ Laurențiu CIORNEI \\ Romanian Academy, Bucharest, Romania \\ laurentiu.ciornei@ince.ro \\ Liviu-Valentin VLĂDUCU \\ Romanian Academy, Bucharest, Romania \\ liviu_vladucu@yahoo.com \\ Getuța DAVID \\ Romanian Academy, Bucharest, Romania \\ getutadavid@yahoo.com
}

\begin{abstract}
The Kurzarbeit model was applied by several European governments during the previous crisis of 2008-2009 and involved the design of small state-funded work schemes. Governments have supported subsidized companies to compensate for the loss of revenue. Adapting the model to the crisis has been much easier in countries where regulation already exists, compared to the countries that adopted it for the first time. The efficiency of the model was different, with the best results being obtained by countries that had robust economies before the crisis. Overall, at the level of countries that have applied this model, it can be said that the model provided job stability during the crisis, not the certainty that workers will keep their jobs even after the crisis. Given the recent decision of the Romanian Government to apply the Kurzarbeit measure in our country as well, in the current study we considered the analysis of those issues that affected the countries that adopted this model for the first time, in the previous crisis, at which we added the unprecedented impact of the recent pandemic and the particular aspects that characterize today's Romanian economy. The results show that, without analyzing the particularities that differentiate Romania from the countries that have successfully applied the model, the Kurzarbeit model will not ensure the sustainable development of the social factor and the employment rate assumed for 2020, and social inequalities and poverty will continue to deepen.
\end{abstract}

Keywords: sustainable development, Kurzarbeit, employment rate, social inequality, poverty rate.

\section{Introduction}

Short-term work is defined as a temporary reduction of the work schedule, meant to maintain an existing employer/employee relationship. This can be either a partial reduction of the normal working hours for a limited period (a partial suspension of the employment contract) or a temporary dismissal (a complete suspension of the employment contract by zero hours per week). In both cases, the employment contract is retained. Short-term work is designed to give employers the opportunity to temporarily adjust their work schedule (and thus maintain internal flexibility) without ending the employment relationship. This aspect must allow for the continuity of activity while maintaining the degree of employment, an essential element of sustainable development, for 
the reduction of poverty and social inequalities, with major cross-cutting effects on other sustainable development objectives.

\section{Problem statement}

In the context in which companies operate in a risk-neutral environment and under the conditions of unrestricted insurance of employees, the appearance of dismissal is excluded (Burdett and Wright, 1989). When financial constraints arise, similar to those at the time of financial crises, short-term work systems can contribute to maintaining a balance and maintaining jobs (Braun et al., 2011).

From an analysis of the effects of short-term work during the 2008-2009 financial crisis, some studies have confirmed that short-term work helps corporations cope much better with the crisis. Hijzen and Venn (2011) estimate that short-term work may be relatively widespread in the context of an economic downturn, when more firms face financial difficulties, but is likely to be limited during the economic recovery when economic activity an ascending slope.

The effects of the recent pandemic (Covid-19) and the global risk of recession are prerequisites for the onset of the largest global economic crisis. The effects of the pandemic and thus the isolation measures hit the OECD economies, millions of people did not have access to work, which led to a sharp decline in activity and significant job losses, with situations in which the number of hours worked was found, in some countries it was up to 10 times less compared to the first few months of the financial crisis of 2008 (OECD, 2020).

Out of the need to respond quickly to the shock wave that is spreading around the world and in Europe, especially affecting the social pillar, Germany has reintroduced the Kurzarbeit model, an aid scheme that allows companies to reduce working time and thus revenue by paying the difference by the state.

This model gained momentum in many European countries and reached Romania, under the recommendation of the European Union to be implemented in all member countries.

\section{Research questions}

Romania has undertaken to maintain, by the end of 2021, an employment rate of $70 \%$, a level it reached at the end of 2019. Will Kurzarbeit manage to maintain this employment rate so that the objectives of sustainable development are not affected? This question needs to be answered, given that more than half of the 17 sustainable development goals relate to the social pillar. Poverty eradication, combating inequality, ensuring well-being and developing an economy centered on ethical principles are internationally established, in response to the latest financial crisis that has largely affected the social factor.

\section{Research Methods}

In order to deduce to what extent the Kurzarbeit model will help Romania to overcome the crisis wave brought by the Covid-19 pandemic, in the current study we considered the comparative analysis of the problems faced by other countries in the European Union, in the previous crisis, and the conclusions that these countries drew, with the application of this model, for the first time. In addition, we also considered the implications of digitalization, brought about by the fourth industrial revolution. 


\section{Different application}

First of all, it should be noted that the Kurzarbeit model has been implemented differently in EU countries in response to the different slowdown in economic growth. Different institutions were involved in the process, the model being designed by ministries (for example, the German Ministry of Labor and Social Affairs) and implemented by employment agencies with the direct involvement of the social partners (trade unions and industry associations, sometimes also multinational companies) in all political discussions on this issue. Adapting the model to the crisis has been much easier in countries where regulation has already existed, with the procedures, social effects, advantages and disadvantages of employment agencies and the social partners being known. The Kurzarbeit model was financed differently from country to country: only by providing the unemployment fund (in the old EU Member States) or from the state budget and the European Social Fund (the new Member States).

\section{Correct information}

It was important for employers and employees to be well informed about what short-term work entails. Ministries, employment agencies and other stakeholders have played an important role in informing employers and workers. Inadequate knowledge of the Kurzarbeit model reduced participation, increased ambiguity, and reduced effects as such.

\section{Efficient communication}

As soon as the framework of the Kurzarbeit model was created, companies, professionals, chambers of employment and employment agencies, in particular, were asked to implement the measures. The short-term job application procedure (with small differences from country to country) required a prior agreement with the unions (in countries where a partner agreement was required), justification of the economic need and the list of potential employees. participants. The agencies checked that the employers/employees met all the conditions for participation in the program and, in case of uncertainties, the agencies addressed the employers or requested additional documents. Only after the applications were verified and participation in the short-term work program was approved, the employer could implement the measure. During the short-term activity, the employer had to report regularly how many employees participate in short-term work and to what extent. This information was verified by the employment agency to prevent abuses of the system.

\section{Sectors of activity affected differently}

The number of participants varied significantly between different countries, with short-term work not being evenly distributed throughout the economy. Most of the workers affected by short-term work were men aged between 30 and 50, skilled workers with average incomes, such as car operators. This category of workers was a vulnerable one, being workers who would have found it difficult to find jobs after the crisis. This measure benefited, to a greater extent, workers with an employment contract of indefinite duration compared to temporary workers.

\section{The context and development of the economy}

The effectiveness of the measures also depended on the context and development of the economy during the crisis. Short-term work could be classified as efficient if no structural adjustment of the economy was necessary. In other words, the effectiveness of this model depended on the robustness of the economies before the crisis. 


\section{Changes that occurred during the crisis}

None of the short-term work patterns were perfect as a result of changes during the crisis. The basic mechanisms of short-term work were not affected, but the balance between flexibility and rigor, between public and private contributions, between employer and employee was adjusted to make the model more attractive. With many variables involved, they could be adjusted to create different effects.

PICBE |

1222

\section{No certainties}

The Kurzarbeit model provided job stability during the crisis and not the certainty that workers would keep their jobs after the crisis. Sustainable job development has not been guaranteed by this model. The companies benefited from the continuation of economic activities with public funds.

\section{Differences from the previous crisis}

Compared to the previous crisis, there was an acceleration of the fourth industrial revolution, which changed the conditions of application to a certain extent. Thus, the Kurzarbeit model had to differentiate between employers/employees who digitized their work processes and those who continued to rely on traditional processes. Moreover, the imposed social isolation made the difference between employers/employees who were able to continue working from a distance and those who needed physical presence at work. This has led to a different impact on the sectors of activity and differences between countries in the period of applicability of the reduced work program and the share with which the state is willing to participate in this regard. The sector most affected was the services sector, especially HoReCa, compared to the production sector in the previous crisis. According to a recent study (Euler Hermes, 2020), in 2020, Germany was willing to cover between $60 \%$ and $87 \%$ (in special cases) of gross salary, including social contributions due by employers, for a period between 12 and 24 months (in special cases) with a limit of monthly income between 6,450 - 6,900 euros. France subsidizes $84 \%$ of the net salary (or $70 \%$ of the gross) and $100 \%$ for those with a minimum wage, and from 01.06 .2020 the percentage is $71 \%$, for a maximum period of 6 months-1.2 years. The hourly income is between $7.23-7.74$ euros, and the number of hours that can be reduced is 1,607 hours / year. Italy bears $80 \%$ of the initial salary of the pandemic crisis, for companies with more than 5 employees, for an initial period of 9 weeks, which was extended until the end of August, and in exceptional cases until the end of October 2020, compared to the previous crisis, when the period covered was three years. The allowance varies between 939 - 1,129 euros, depending on the salary you had before the pandemic. Spain covers $70 \%$ of the salary in the first 6 months, then $50 \%$ of it, regardless of the number of employees. The United Kingdom granted an allowance of between 80\% (until August 2020) and $60 \%$ (until October) of the salary received before isolation.

\section{Particularities that characterize Romania, in the application of the Kurzarbeit model}

The crisis generated by the Covid-19 pandemic, the isolation measures established by the authorities and the fear of employees to become infected have led to the withdrawal of activities in many economic sectors. This has led the government to support employers and employees by adopting several support measures. Their purpose was to ensure the support of companies and to balance the unemployment rate. Thus, by promulgating GEO no. 132/2020, GEO 211/2020 and Law 282/2020, the German Kurzarbeit model was also adopted by Romania (Table 1). 
Table 1. Support measures adopted in Romania

\begin{tabular}{|c|c|c|c|c|}
\hline Lega1 Framework & Eligible categories & Beneficiaries & State aid cap & Duration \\
\hline \multirow{6}{*}{ GEO no. $132 / 2020$} & \multirow{6}{*}{$\begin{array}{c}\text { Employers who } \\
\text { cumulatively meet } 3 \\
\text { conditions: } \\
\text { 1). The reduction of } \\
\text { the activity is } \\
\text { determined by the } \\
\text { establishment of the } \\
\text { state of emergency } / \\
\text { alert; } \\
\text { 2). At least } 10 \% \text { of } \\
\text { the total number of } \\
\text { employees are } \\
\text { affected; } \\
\text { 3). Decrease } \\
\text { turnov er by at least } \\
10 \% \text {. }\end{array}$} & $\begin{array}{l}\text { 1) emp loyees receive a } \\
\text { maximum of } 50 \% \text { of the salary } \\
\text { from the emp loyer and an } \\
\text { allowance. }\end{array}$ & $\begin{array}{l}75 \% \text { of the } \\
\text { difference } \\
\text { between the } \\
\text { gross basic } \\
\text { salary provided } \\
\text { in the CIM and } \\
\text { the salary } \\
\text { corresponding } \\
\text { to the hours } \\
\text { actually worked, }\end{array}$ & $\begin{array}{l}\text { until } 31.12 .2020 \\
\text { (tmin imum } 5 \\
\text { cons secutive working } \\
\text { days and traximum } \\
50 \% \text { of the monthly } \\
\text { working time) }\end{array}$ \\
\hline & & 2) professionals & \multirow{2}{*}{$\begin{array}{l}41.5 \% \text { of the } \\
\text { average annual } \\
\text { gros s eamings }\end{array}$} & \multirow[b]{2}{*}{ until 31.12 .2020} \\
\hline & & $\begin{array}{l}\text { 3) pers ons who have } \\
\text { concluded individual labor }\end{array}$ & & \\
\hline & & 4) day laborers & $\begin{array}{l}35 \% \text { of daily } \\
\text { remuneration }\end{array}$ & idem \\
\hline & & $\begin{array}{l}\text { 5) emp loyers for new } \\
\text { employment contracts }\end{array}$ & $\begin{array}{l}41.5 \% \text { of the } \\
\text { related salary. }\end{array}$ & idern \\
\hline & & $\begin{array}{l}\text { 6) emp loyers for employees in } \\
\text { telework }\end{array}$ & $\begin{array}{l}2,500 \text { lei } / \\
\text { employee }\end{array}$ & idem \\
\hline GEO no. $211 / 2020$ & idem & 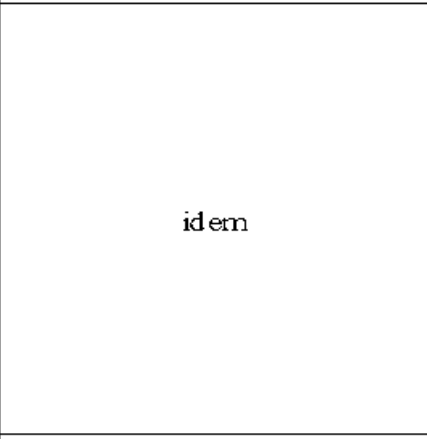 & idem & $\begin{array}{l}\text { Extends the } \\
\text { measures for } \\
\text { granting support, for } \\
\text { all areas of activity } \\
\text { provided by Law no. } \\
55 / 2020 \text {, until } \\
30.06 .2021 \text { (minimum } \\
5 \text { working days per } \\
\text { month, maximum } \\
80 \% \text { of the duration } \\
\text { provided in the } \\
\text { CIM). }\end{array}$ \\
\hline Law $282 / 2020$ & idem & idem & idem & $\begin{array}{l}\text { Extends up to a } \\
\text { maximum of } 3 \\
\text { months from the end } \\
\text { of the emergency / } \\
\text { a lert state (maximum } \\
50 \% \text { duration of } \\
\text { working time, } \\
\text { minimum } 5 \text { working } \\
\text { days / month). }\end{array}$ \\
\hline
\end{tabular}

Source: Processing of authors based on information taken from existing legal regulations at the national level, http://legislatie.just.ro/.

The legal alternative that was offered to employers, whose businesses were affected by the pandemic generated by Covid-19, was the subsidy by the state of the reduced and flexible working time of the employees, so that the salary incomes are not affected much, avoid mass redundancy measures. Until the onset of the state of emergency, compared to employees in EU-28 countries, in terms of the number of hours worked per week, employees in Romania had a work schedule above the EU-28 average, both in terms of full-time and and from the perspective of the part-time program (Figure 1). 


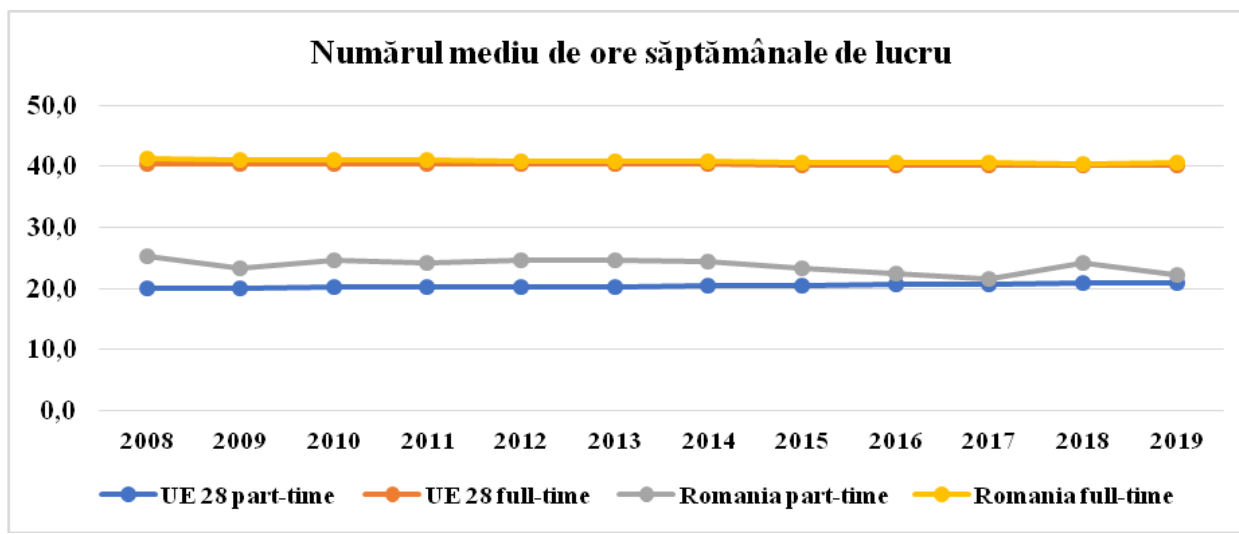

PICBE |

Figure 1. Evolution of the number of weekly working hours, 2008-2019

Source: Processing of authors based on Eurostat data (2020).

During the state of emergency, in the absence of any previous experience in carrying out the activity in conditions of epidemiological risk, as an alternative to the reduced work schedule, the organizational measures aimed at using alternative forms of work, including working from home, which influenced work program dynamics. In this context, the telework regime was regulated, taking advantage of the digitization and computerization of activities that could be performed remotely. The telework regime limited the number of beneficiaries of the Kurzabeit model, but not all sectors of activity were able to benefit from remote work.

Certain activities in communications services, electricity supply, heat, drinking water and household water, food supply and sales chains have presupposed the physical presence of employees in the workplace, being strategic sectors that have ensured continuity. Equally, for employees in the forestry sector, directly involved in the activity of harvesting raw wood, a source of heating and food preparation for more than 50\% of the country's population, physical presence at work was required. In the HoReCa sector, even if it was severely affected, it was not possible to reduce the work schedule. According to the study conducted by the HoReCa Industry, this was a segment in which more than 300,000 employees were active, with an average number of 88 employees before the Covid-19 pandemic. Therefore, during the pandemic, on average, 71 employees were sent into technical unemployment and 14 were laid off (https://www.resto graf.ro/studiu-hora-restograf-care-este-situatia-reala-a-restaurantelor-in-contextul-covid-19/).

Other sectors of activity were affected by technical unemployment, especially in trade, the automotive industry and the manufacturing industry.

In the energy sector, which played an important role during the state of emergency, two different approaches emerged on how to carry out activities. On the one hand, there have been situations in which the physical presence of employees has been required, in particular in the energy production and transport sector, situations in which measures have been taken to ensure and equip spaces inside power plants, or to ensure the accommodation of employees in special spaces, in order to avoid a possible illness of the employees who carried out their activity in the strategic objectives. On the other hand, other employees in the energy sector had the opportunity to work in telework, a context in which digitalization played a key role, companies investing in this period in computer technology, means of distance communication, but also in communications security and encryption solutions.

For the Kurzarbeit model, public institutions, entities in bankruptcy, in dissolution, in liquidation or with suspended or restricted activity, at the time of requesting state support, or units 
registered in jurisdictions declared as tax non-cooperating were not eligible. Other sectors have proven resilient, even in the context of this pandemic. The agricultural sector, for example, continued to operate, although a number of activities were severely affected. Wine growing, fishing and aquaculture were among the sectors most affected by the crisis. Demand fell sharply as retailers, restaurants, canteens and other large shoppers reduced or temporarily shut down, and the tourism ecosystem was severely affected by severe traffic and travel restrictions.

Overall, for economic sectors that had to temporarily suspend their activities in order to overcome difficult times and avoid redundancies, employers resorted to reduced work schedules and the authorities provided income to vulnerable people (Table 2).

Table 2. Allowances granted based on GEO 132/2020

\begin{tabular}{|l|c|c|}
\hline \multicolumn{1}{|c|}{ Month } & Beneficiaries & Payments \\
\hline August & 9.759 & 12.362 .052 \\
\hline September & 19.476 & 31.647 .794 \\
\hline October & 24.750 & 42.991 .004 \\
\hline November & 26.387 & 51.714 .159 \\
\hline December & 18.739 & 41.163 .237 \\
\hline Total & 99.111 & 179.878 .246 \\
\hline
\end{tabular}

Source: Processing of authors based on MMANPIS data https://www.mmanpis.ro/category/comunicate/.

As can be seen in Figure 2, the number of people affected by unemployment has been increasing throughout 2020, even after the application of the Kurzarbeit model, which confirms that the impact of the reduced work schedule was not significantly felt in the Romanian economy. Moreover, the number of uncompensated unemployed stood at over $65 \%$ of the total number of people affected by unemployment. Comparing the number of beneficiaries of the Kurzarbeit model to the total number of employees, it appears that only about $2 \%$ of employees benefited from this program. Or, according to a study undertaken by the Romanian Academy, the number of active employees decreased by over 900 thousand people in April 2020 and 340 thousand at the beginning of May (approximately $15 \%$ of the active population). In addition, more than 1 million individual employment contracts were suspended (approximately $18 \%$ of the number of employees). Also, those categories of people who worked without formal and taxed contracts, family workers and those who organized an economic activity on their own were acutely affected by the pandemic (Chivu and Georgescu, 2020).

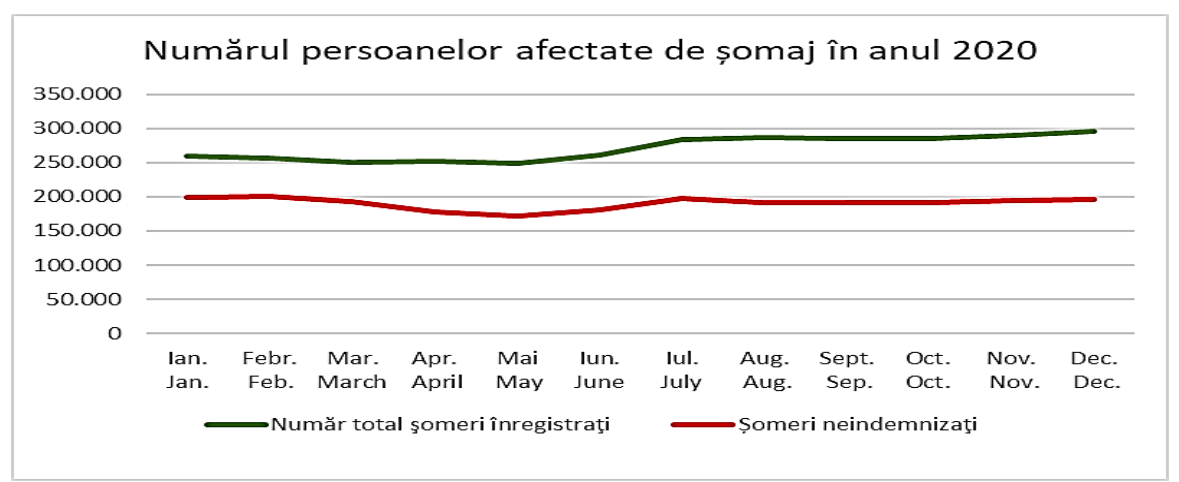

Figure 2. Evolution of the number of people affected by unemployment in 2020

Source: authors' processing based on ANOFM data (2020).

DOI: $10.2478 /$ picbe-2021-0113, pp. 1219-1229, ISSN 2558-9652 |

Proceedings of the $15^{\text {th }}$ International Conference on Business Excellence 2021 
The biggest drawback of the Kurzarbeit model is related to the actual settlement because the allowance must be paid together with the other salary rights, in advance, by the employer, and the amount will be recovered from the unemployment insurance budget, only after fulfilling the declaratory obligations; of the conditions for granting. From this point of view, a number of employers did not benefit from this program, as a result of situations generated by the ambiguities that characterized the state of emergency and alert, regarding the qualification criteria, which were verified by the authorities only after payment. salary rights by employers.

Given these limitations, the advantages brought by the telework regime and the architecture of the Romanian economy, mainly oriented on services and hospitality, make the model less applicable and less efficient compared to the effects in the German economy, mainly oriented on production. This raises the issue of the sustainability of the model, as long as it is foreseen that the effects of the pandemic will be felt beyond the moment when it will be over, accentuated by the digitization that has intensified in the last year.

Once launched, legally recognized and supported by the ongoing digitalization process, the telework regime will continue beyond the pandemic. According to a survey conducted by Boston Consulting Group (BCG), 60\% of employees and 77\% of employers expect to continue working, in whole or in part, from home after the pandemic (BCG, 2021). This aspect will generate a series of changes on the business models that will affect a series of activity sectors, the most affected being the real estate sector, as a result of the restriction of the spaces allocated to office activities. According to the same BCG survey, $60 \%$ of office space remained unused. For these reasons, we advance the idea that the workforce will continue to be affected (it is estimated that approximately $49 \%$ of employees will be affected by mental health), but these causes no longer fall within the scope of the Kurzarbeit model.

And until the date of application of the Kurzarbeit model, in order to limit the effects of the pandemic and manage the state of emergency, financial resources amounting to 5,051 million lei were mobilized until 30.06.2020, the most important allocation being for the payment of the indemnity granted during the suspension of the individual contract. at the initiative of the employer, 3,692 million lei (73.09\%), followed by the allowances granted to other categories of staff whose activities were interrupted or took place at a very low level, 662.8 million lei (13.12\%) (Court of Accounts, 2020). These amounts far exceeded the financial resources allocated for the social protection of the unemployed throughout 2010, in the amount of 3,822 million lei, a year in which the previous crisis was strongly felt in Romania (Figure 3).

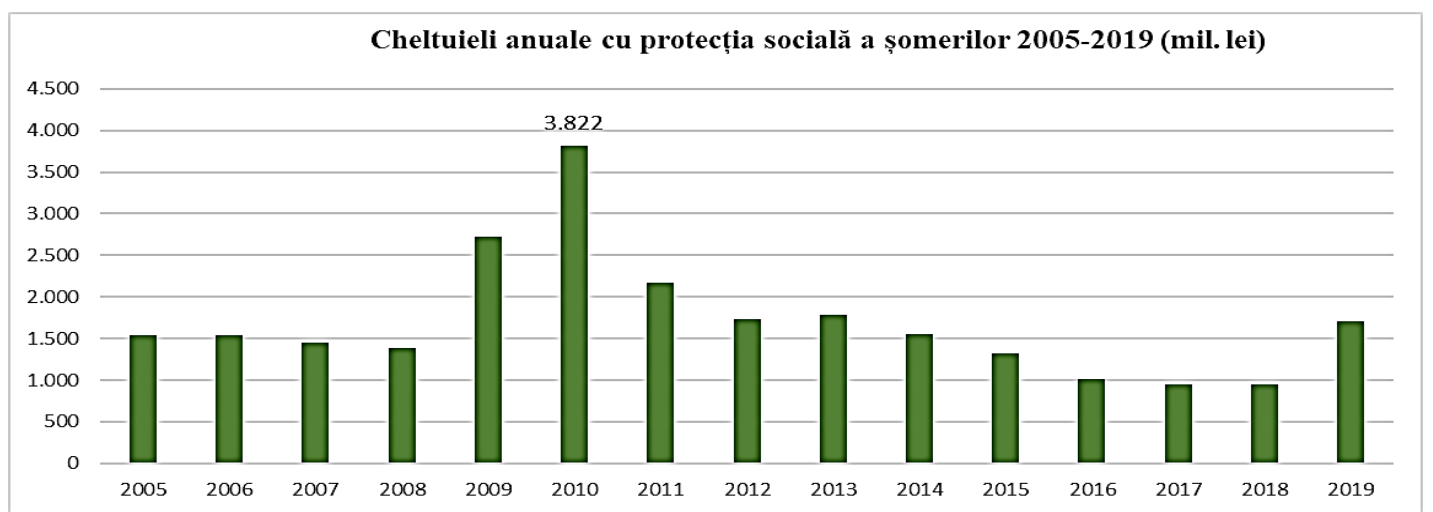

Figure 3. Evolution of spending on social protection of the unemployed, 2005-2019

Source: authors' processing based on INSSE data (2020).

DOI: 10.2478/picbe-2021-0113, pp. 1219-1229, ISSN 2558-9652 |

Proceedings of the $15^{\text {th }}$ International Conference on Business Excellence 2021 
Given the limitations of the Kurzarbeit model, the Emergency Risk Mitigation Support Tool (SURE) has helped to keep jobs and help families. The amounts settled through other measures to support and recover the severely affected sectors were much higher than those settled through the Kurzarbeit model, and the effects were much more visible. State aid has played a key role. However, these aspects are not the subject of the current study.

\section{Findings}

The Kurzarbeit model provided job stability during the previous crisis, but not the certainty that workers would keep their jobs after the crisis. Sustainable job development has not been and is not guaranteed by this model. Companies benefited from the continuity of economic activities with public funds, but social inequalities and the poverty rate continued to deepen both in Europe and in Romania. Compared to the previous crisis, digitalisation and isolation measures are risk factors that increase the likelihood that the Kurzarbeit model will not achieve its goals. For the model to have a lasting impact on the economic and social factor, the authorities and decision-makers must impose a certain set of conditions that companies must meet after the exit from the crisis.

In Romania, the measures ordered by the authorities have complicated the process and reduced participation. Moreover, without a sound analysis, overview and convergent measures, the funds made available by the authorities, coming from various loan agreements, with or without advantageous conditions, put pressure on future generations. Measures can only be effective if they allow resilience after shock. Or, from this point of view there is a certain uncertainty, given the change of business models globally, which will be felt in the Romanian economy, through the network of multinational companies that will adopt the models imposed by the groups they belong to. These changes include the change in production and supply chains, digitalization, the telework regime and many other aspects that characterize the dynamics of the global economy.

\section{Discussions}

The effectiveness of the Kurzarbeit measure has been positive in most countries, with short-term work saving many jobs. However, there have been situations in which workers have been laid off after the crisis, at a time when there has been less uncertainty about the direction of the global economy. Moreover, the effectiveness of the measures also depended on the context and particular development of the economies during the crisis. Or, at present, the global economic context is marked by fundamental changes, an aspect that is accentuated by the Covid-19 pandemic and by the reaction capacity of each economy, in the direction of diminishing the negative effects that hover over the social pillar.

In Romania, there are all the prerequisites for the Kurzarbeit model not to achieve its intended purpose. The number of beneficiaries is far too small compared to the number of employees affected by the crisis. The pandemic is still present, the alert has not ended, and unemployment funds are depleted. Even if the funds from the European Union could solve the problem of unemployment, this solution could "sweeten" Romania's situation only in the short term, because, in the medium and long term, structural reforms are needed to ensure the construction of the entire economy. sustainable development, to be given to global change.

\section{Conclusions}

It has been shown globally that increasing employment or maintaining the employment rate through various solutions, such as the Kurzarbeit model, has not had a positive impact on the 
quality of life as a whole. The poor population has grown and the middle class has shrunk. Romania has failed, in all these years, since joining the European Union, to raise the living standards of its citizens too much. Even though the number of those engaged in employment has increased, onefifth of them remain poor. This shows that the measures taken so far have not been effective or sustainable. To what extent the Kurzarbeit model will be able to cover pre-pandemic deficiencies, mitigate the effects of pandemics and digitization is difficult to predict now, but could be measured with the publication of the first post-pandemic statistics. What is certain is that Romania did not take into account the experiences of the countries that applied this model in the previous crisis. Otherwise, the ambiguities that characterized the qualification conditions and the effective settlement would have been avoided, and the number of beneficiaries would have been much higher. In fact, the impact of telework and digitalization during the pandemic has contributed to reducing the number of employers who have applied this model. In this sense, our study will be continued, in order to formulate conclusions and identify mitigation measures for a significant share of the risk scenarios that Romania must consider, if it wants a sustainable, modern and resilient economy.

\section{References}

Braun, H., Brügemann, B., Michalek, K. (2011). "Welfare effects of short-time compensation”. presented at IZA Workshop "Unemployment Insurance in the Recession".

Burdett, K., Wright, R. (1989). "Unemployment insurance and short-time compensation: the effects on layoffs, hours per worker, and wages". J Polit Econ 97(6), 1479-1496.

BCG (2021). New Ways of Working Smart Work. Boston Consulting Group. Available at: https://web-assets.bcg.com/ab/fa/dccfcb7344d88f6a6a0918c3cd4b/smart-work-kiadvanyv12-final-margit.pdf.

Chivu, L., Georgescu, G. (2020). Vulnerabilities of the labor and employment market in the context of the covid-19 pandemic. Possible solutions. Available at: https://academiaromana.ro/ SARS-CoV-2/doc/d04-Vulnerabilitati_ale_pietei_muncii.pdf.

Curtea de Conturi (2020). Management of public resources during the state of emergency - Special report made at the request of the Romanian Parliament. Available at: http://www.curtea deconturi.ro/Publicatii/Raport_stare_urgenta_11082020.pdf.

Eurostat (2020). Average number of usual weekly hours of work in main job, by sex, professional status, full-time/part-time and economic activity (from 2008 onwards, NACE Rev. 2) hours, cod: lfsa_ewhun2, disponibil la: http://appsso.eurostat.ec.europa.eu/nui/submitView TableAction.do.

Hijzen, A., Venn, D. (2011). "The role of short-time work schemes during the 2008-09 recession", OECD social, employment and migration working papers no. 2010/15, OECD Publishing, Paris.

IEA (International Energy Agency) (2017). World Energy Outlook. OECD/IEA, Paris 2017. Available at: https://www.iea.org/reports/world-energy-outlook-2017.

National Institute of Statistics (2020). Annual expenditures with social protection of the unemployed by categories of expenditures, macro-regions, development regions and counties. Available at: http://statistici.insse.ro:8077/tempo-online/\#/pages/tables/inssetable, cod SOM102A.

OECD (2020). COVID-19 is causing activity to collapse and unemployment to soar, Disponibil: http://www.oecd.org/employment-outlook/2020/\#country-data. 
GEO on support measures for employees and employers in the context of the epidemiological situation caused by the spread of SARS-CoV-2 coronavirus, as well as for stimulating employment growth no. 132/2020. Official Gazette of Romania, Part I, no. 720.

GEO regarding the extension of the application of some social protection measures adopted in the context of the spread of the SARS-CoV-2 coronavirus, as well as for the modification of the Government Emergency Ordinance no. 132/2020 on support measures for employees and employers in the context of the epidemiological situation caused by the spread of SARS-CoV-2 coronavirus, as well as to stimulate employment growth, no. 211/2020. Bucharest: Official Gazette of Romania, Part I, no. 1189.

Law no. 282/2020 for the approval of the Government Emergency Ordinance no. 132/2020 on support measures for employees and employers in the context of the epidemiological situation caused by the spread of SARS-CoV-2 coronavirus, as well as to stimulate employment growth. Bucharest: Official Gazette of Romania, Part I, no. 1201.

https://ec.europa.eu/info/live-work-travel-eu/coronavirus-response/jobs-and-economy-during-cor onavirus-pandemic_ro.

https://www.mmanpis.ro/category/comunicate/.

https://www.allianz.com/content/dam/onemarketing/azcom/Allianz_com/economic-research/pub lications/specials/en/2020/june/2020_6_17_labor_market.pdf.

http://statistici.insse.ro:8077/tempo-online/\#/pages/tables/insse-table, cod SOM102A.

https://www.restograf.ro/.

https://www.anofm.ro/.

DOI: 10.2478/picbe-2021-0113, pp. 1219-1229, ISSN 2558-9652 |

Proceedings of the $15^{\text {th }}$ International Conference on Business Excellence 2021 